\title{
Late-glacial and early Holocene lake sediments, ground- water formation and climate in the Atacama Altiplano 22-24 ${ }^{\circ}$ *
}

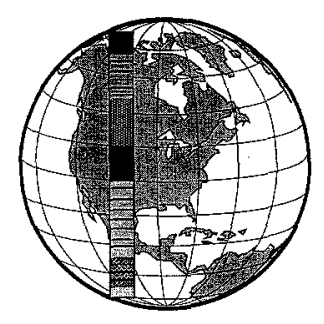

\author{
Martin Grosjean ${ }^{1}$, Mebus A. Geyh ${ }^{2}$, Bruno Messerli $^{3}$ \& Ueli Schotterer ${ }^{4}$ \\ Resource Management Science and Environmental Studies, University of British Columbia, 2206 East Mall, V6T \\ $1 Z 3$ Vancouver, Canada; ${ }^{2}$ State Geological Survey Lower Saxony, 30655 Hannover, Germany; ${ }^{3}$ Department of \\ Geography, University of Bern, 3012 Bern, Switzerland; ${ }^{4}$ Department of Environmental Physics, University of \\ Bern, 3012 Bern, Switzerland
}

Received 26 September 1994; accepted 20 February 1995

Key words: fossil groundwater, reservoir effect, seasonally-laminated sediments, subtropical Andes, paleomonsoon

\begin{abstract}
Precipitation rates in the Atacama Altiplano $22-24^{\circ} \mathrm{S}$ were $400-500 \mathrm{~mm} \mathrm{yr}^{-1}$ during late glacial and early Holocene times as opposed to $200 \mathrm{~mm} \mathrm{yr}^{-1}$ today. This humid phase (Tauca phase) was likely due to strenghtened tropical (monsoonal) circulation, which brought continental moisture to the Atacama Altiplano. The lake level of Laguna Lejía $\left(23^{\circ} 30^{\prime} \mathrm{S}, 4350 \mathrm{~m}\right.$ ) at that time was up to $25 \mathrm{~m}$ higher than it is today. $\mathrm{Mg} / \mathrm{Ca}$ and $\mathrm{Sr} / \mathrm{Ca}$ data from lake sediments show that, what today is a highly saline lake was a freshwater lake at that time. Seasonally-laminated calcareous sediments were deposited between 13500 and $<10400 \mathrm{yr}$ B.P. indicating the maximum of the humid phase. Climatic changes in the past are important for current groundwater resources. ${ }^{14} \mathrm{C}$ and ${ }^{3} \mathrm{H}$ data from lake-, ground- and well water suggest that modern groundwater formation (i.e. water $<40$ years) in the Altiplano is very limited under current arid conditions. We conclude that significant amounts of the water resources in this area originated during the time of the late-glacial and early Holocene humid climate. Tritium data from snow samples show that the moisture in the Altiplano at $22-24^{\circ} \mathrm{S}$ is mainly of continental origin, whereas precipitation from the westerlies hardly contributes to the water supply in this area. This precipitation pattern matches the paleodata, and we suggest that current precipitation formation may provide an analogue framework for late-glacial circulation in this area.
\end{abstract}

\section{Introduction}

Paleomonsoon on subtropical high mountain plateaus has become increasingly important in recent research on climate change. Most studies concentrate on the plateau of Tibet and on northwestern America (Ruddiman \& Kutzbach, 1991). Little is known about the central Andean plateau, the Altiplano. Although relatively small in size, the Altiplano may be important for the environmental history of the entire south American

* This is the 3rd in a series of papers published in this special AMQUA issue. These papers were presented at the 1994 meeting of the American Quaternary Association held 19-22 June, 1994, at the University of Minnesota, Minneapolis, Minnesota, USA. Dr Linda C. K. Shane served as guest editor for these papers. continent and could, therefore, provide insight into the similarities and dissimilarities of past climates in both hemispheres.

The Atacama Altiplano is located between the modern tropical and extratropical rainfall belt. The current climate in this area is extremely dry with less than $200 \mathrm{~mm} \mathrm{yr}^{-1}$ precipitation. Therefore, this environment is highly sensitive to changes in humidity. Evidence of a more humid climate in this area during late-glacial and early Holocene times is found in lacustrine and glacial features, in the properties of paleosols, in the pollen spectra of peat bogs, and in the history of human habitation (Ochsenius, 1986; Nuñez, 1992; Baied \& Wheeler, 1993; Messerli et al., 1993; Grosjean, 1994; Grosjean \& Nuñez, 1994). 


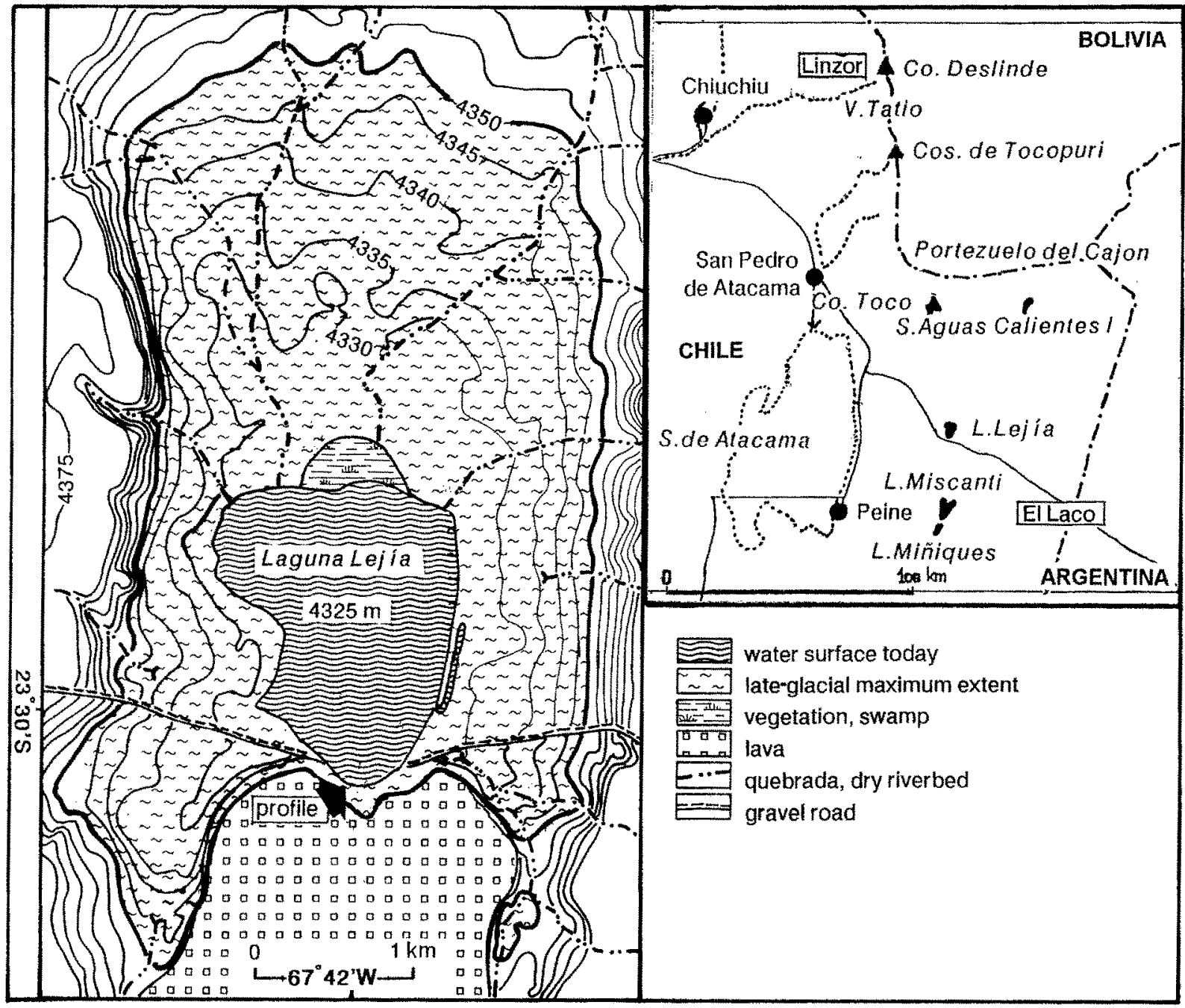

Fig. 1. Research area and map of Laguna Lejía showing the late-glacial maximum extent of the paleolake and the site of the sediment profile.

The lake level history of Laguna Lejía $\left(23^{\circ} 30^{\prime} \mathrm{S}\right.$, $4350 \mathrm{~m}$, Figs. 1 and 2) provides insight into longterm climatic conditions during late-glacial and early Holocene times (Grosjean, 1994). Based on the lake level history of this lake on a water and energy budget model, precipitation is estimated to have varied over the late Pleistocene/early Holocene as follows: less than $350 \mathrm{~mm} \mathrm{yr}^{-1}$ between $c .15400$ to $c$. $13500 \mathrm{yr}$ B.P., $450-500 \mathrm{~mm} \mathrm{yr}^{-1}$ between 13500 to about 10400 yr B.P., and about $400 \mathrm{~mm} \mathrm{yr}^{-1}$ during the early Holocene (Grosjean, 1994). The current precipitation rate is less than $200 \mathrm{~mm} \mathrm{yr}^{-1}$. The lake surface increased during the maximum humid phase by a factor of six, and the lake level was $25 \mathrm{~m}$ higher than it is today (Fig. 1).
Markgraf (1989) and Kessler (1991) have concluded that strengthened monsoonal circulation accounted for the late-glacial humid phase in the Altiplano. Alnus and Podocarpus pollen in the late-glacial sediments of Laguna Lejía, and the lack of late-glacial high lake levels and glacial deposits further south between $25^{\circ} \mathrm{S}$ and $28^{\circ} \mathrm{S}$ provide evidence of strengthened monsoonal precipitation during late-glacial times as far south as $24^{\circ} \mathrm{S}$ (Messerli et al., 1993; Grosjean, 1994).

However, little is known about short-term climatic fluctuations during this humid phase. Another question concerns the impact of this past humid climate on modern water resources: how renewable are the water resources in this dry area? Groundwater use is presently a subject of political controversy due to 

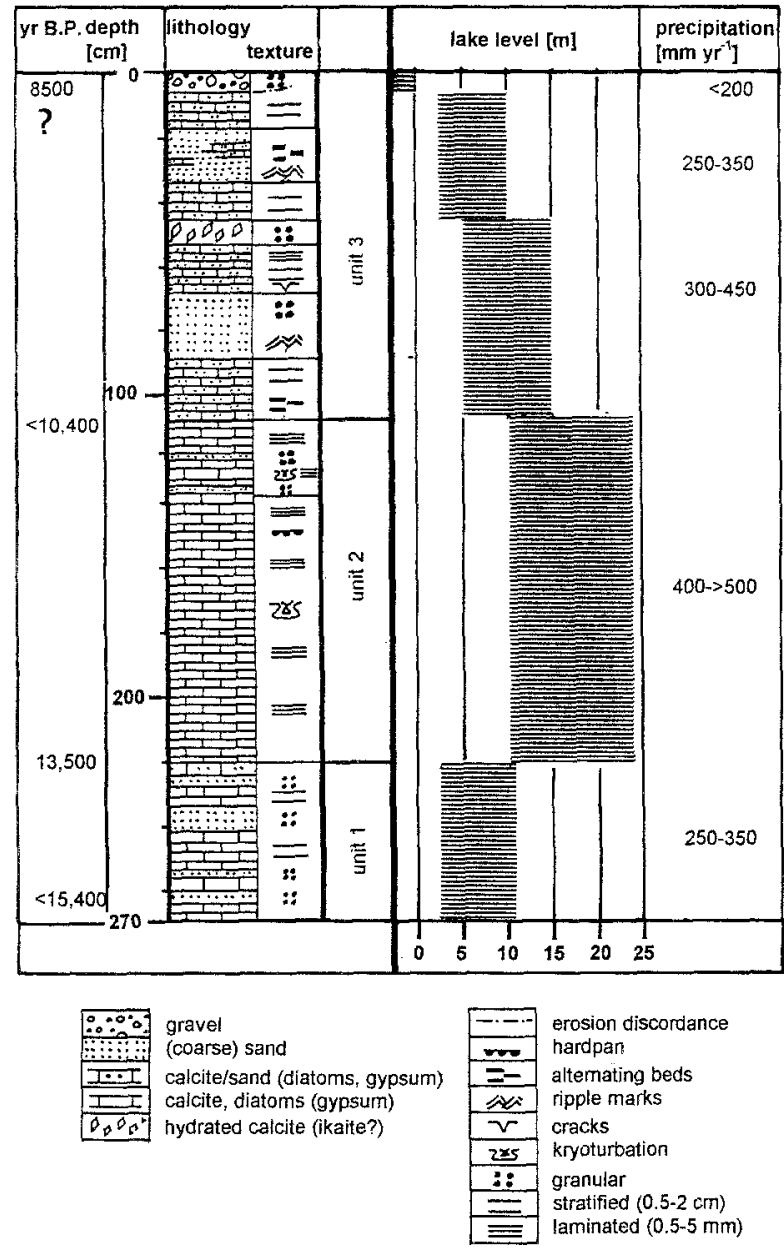

Fig. 2. Stratigraphy of Laguna Lejía and the three major sediment units (southern shore, see also Fig. 3). The lake level history and the respective precipitation rates are modified after Grosjean (1994).

urbanisation, tourism, and rapidly increasing demands for copper.

The purpose of this article is to characterize the lateglacial and early Holocene climate based on lake sediments, and to discuss the significance of past humid conditions for present water resources in the Atacama Altiplano. The research area is shown in Fig. 1. The chemical and mineralogical composition of the laminated late-glacial lake deposits of Laguna Lejía is described in order to evaluate their potential as highresolution records of former climatic conditions. The difficulty of ${ }^{14} \mathrm{C}$ dating of lake sediments due to the reservoir effect in a closed basin is illustrated by an example from sediments of the Laguna Lejía. ${ }^{3} \mathrm{H}$ tritium data on precipitation (snow), ${ }^{14} \mathrm{C}$ and ${ }^{3} \mathrm{H}$ data on groundwater, and surface water allow the modern pre- cipitation component and its origin to be identified. The present-day recharge rate in the water cycle and/or old water components can be evaluated; this in turn provides insight into the linkage between the late-glacial lakes and current water resources in this area.

\section{Methods}

Cores of lake sediment outcrops at the southern shore of Laguna Lejía were collected using PVC tubes. Powdered bulk samples were analyzed for mineralogy with $\mathrm{X}$-ray diffraction (XRD). Bulk sediment samples were digested in $1 \% \mathrm{HCl}$, and $\mathrm{Ca}, \mathrm{Mg}$ and $\mathrm{Sr}$ were analyzed using inductively coupled argon plasma atomic emission spectroscopy (ICAP-AES). $\mathrm{SO}_{4}^{2-}$ was measured using a Lachat Autoanalyzer (turbidimetric method), and inorganic carbon with a Leco C Analyzer. Vertical thin-section were prepared using O'Sullivan's (1983) method. Mineralogy and chemical composition of individual laminae were determined by XRD and energy dispersive $\mathrm{X}$-ray spectroscopy (SEM-EDX). The SEM-EDX analysis comprised the elements $\mathrm{Na}, \mathrm{Mg}$, $\mathrm{Al}, \mathrm{Si}, \mathrm{S}, \mathrm{Cl}, \mathrm{K}, \mathrm{Ca}$ and $\mathrm{Fe}$, giving $100 \mathrm{wt} \%$ (see sediment section $115-120 \mathrm{~cm}$ in Fig. 3). The results for $\mathrm{Na}, \mathrm{Cl}, \mathrm{K}$, and $\mathrm{Fe}$ are not discussed in this study.

Chivas et al. (1986) used molar $\mathrm{Mg} / \mathrm{Ca}$, and $\mathrm{Sr} / \mathrm{Ca}$ ratios in ostracode shells as indicators for paleotemperatures and paleosalinity. In order to obtain a highresolution annual paleohydrological record, the $\mathrm{Mg}$ distribution in calcite within individual laminae was determined by measuring the d-spacings of the calcite lattice by XRD (Goldsmith \& Graf, 1958). Among other trace elements, $\mathrm{Mg}$ and $\mathrm{Sr}$ may replace $\mathrm{Ca}$ in calcium carbonate lattice positions as well as in non-lattice sites (Tucker \& Wright, 1990). The partitioning of $\mathrm{Mg}$ and $\mathrm{Sr}$ in the calcite lattice depends on the concentrations of $\mathrm{Ca}, \mathrm{Mg}$, and $\mathrm{Sr}$ in the host water, on kinetic effects such as precipitation rate, and probably on other factors (organic matter). Unlike Sr, partitioning of $\mathrm{Mg}$ is strongly influenced by temperature (Tucker \& Wright, 1990: 299). Mg and Sr are useful as indicators of paleosalinity and paleotemperature because partitioning is not affected by redox state. However, in a natural system like Laguna Lejía it is most difficult to identify all controlling factors, and precipitation of gypsum is also likely to affect the $\mathrm{Mg} / \mathrm{Ca}$ ratio in the host water. Therefore, changes in ratios of $\mathrm{Ca}, \mathrm{Mg}$, and $\mathrm{Sr}$ in magnesian calcite may be interpreted only qualitatively with respect to salinity and temperature changes. 


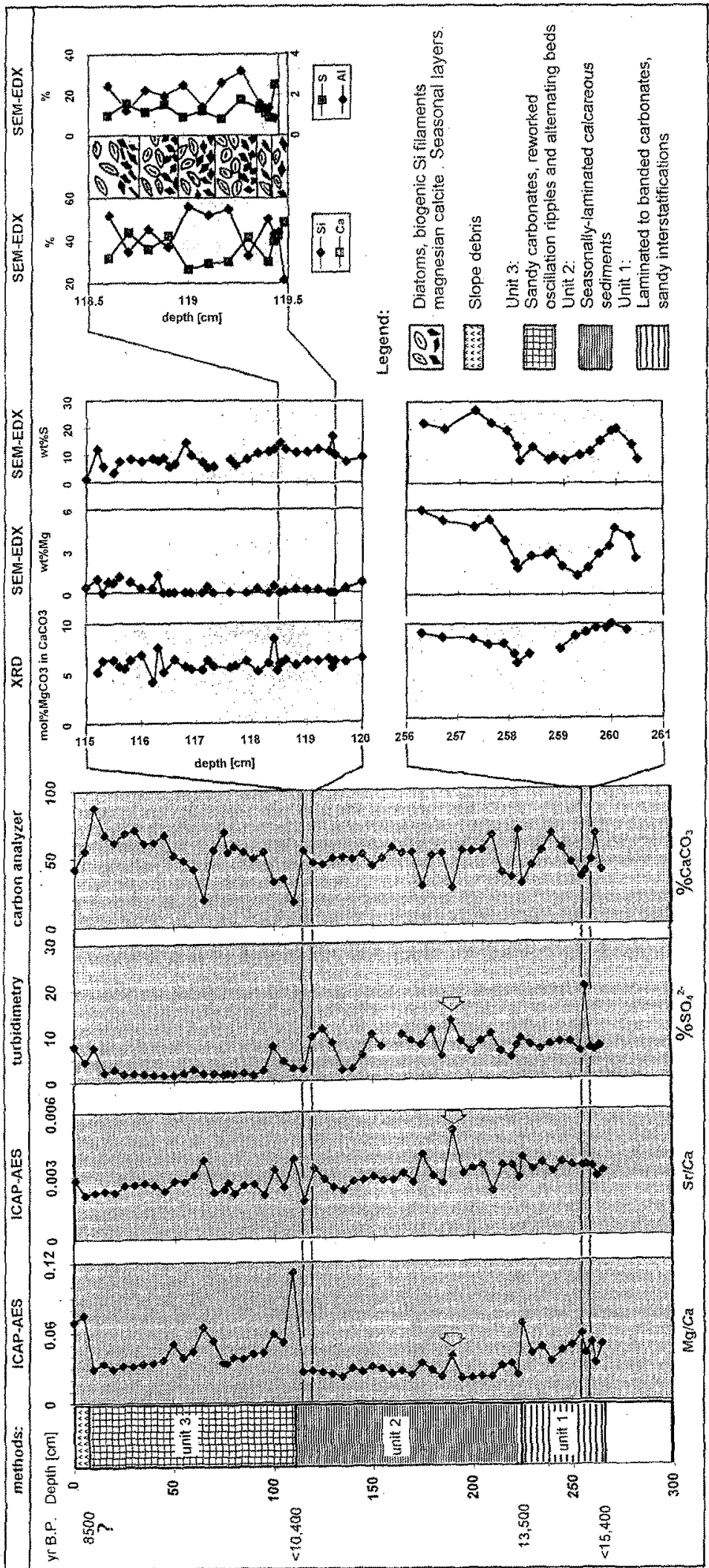

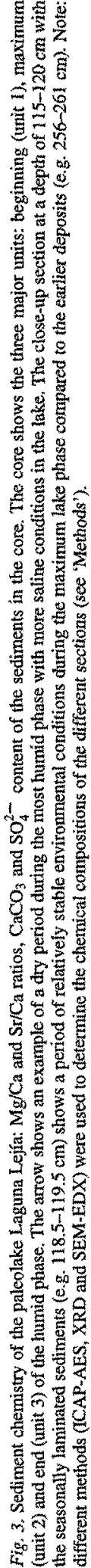


Macroscopic terrestrial organic matter (OM) is lacking in the sediments. Therefore, both the total OM and the inorganic carbonates were used separately for radiocarbon dating. Thermoluminescence dating of the polymineral fractions $4-12 \mu \mathrm{m}$ in volcanic ash layers within the lake sediments (Bürgi, 1992) was used to provide carbon-independent dates.

In order to estimate the reservoir effect, the dissolved inorganic carbon compounds (DIC) in groundwater, lake water and spring water were precipitated as $\mathrm{BaCO}_{3}$, and analyzed for ${ }^{14} \mathrm{C}$ (percent modern carbon $\mathrm{pMC}$ ) and $\delta^{13} \mathrm{C}(\% \circ \mathrm{PDB})$. To minimize outgassing and fractionation of carbon as $\mathrm{CO}_{2}$, the $\mathrm{pH}$ milieu was kept high ( $>8$ ) during precipitation by addition of $\mathrm{NaOH}$.

The modern component in the water cycle was identified by tritium measurements. Direct gas counting in a low-background underground laboratory allowed us to detect concentrations as low as 0.4 TU (tritium units). ${ }^{3} \mathrm{H}$ originated in the atmosphere from nuclear weapon tests in the 1950s and is, therefore, a tracer for modern meteoric water, i.e. water younger than 40 years. Measurements of modern rainfall (IAEA/WMO, 1994) in Salta (NW Argentina) yielded more than 4 TU for tropical, continental moisture, whereas rainfall from the Pacific shows significantly lower tritium concentrations $(<2 \mathrm{TU})$. Therefore, moisture advection from the continent can be clearly identified in precipitation samples with more than 2 TU.

\section{Results and discussion}

\section{Sedimentology, chemistry and mineralogy of Laguna Lejía}

Figures 2 and 3 show the sedimentology and selected chemical compounds of the paleolake Lejía.

The sediment section is divided into three major units: The sediments of the first unit $(225-270 \mathrm{~cm}$ deep, c. 15400 to $c .13500{ }^{14} \mathrm{C}$ yr B.P. with reservoir correction) consist of a) a sublittoral sediment facies with laminated $(1 \mathrm{~mm})$ to banded $(<3 \mathrm{~cm})$ micrite with magnesian calcite, gypsum, traces of quartz and plagioclase, and diatoms, and b) a littoral facies with $1-3 \mathrm{~cm}$ thick sand layers with magnesian carbonate coatings of charophytae, and c) thin layers $(<0.5 \mathrm{~cm})$ of gypsum crystals. The relatively high $\mathrm{Mg} / \mathrm{Ca}$ ratio in the HCl-soluble fraction of the sediments (Table 1), the strongly fluctuating calcite content, and frequent changes between littoral and sublittoral facies suggest varying environmental conditions. The erosion rates on the adjacent slopes were considerable, and the environmental conditions in the lake and in the surrounding areas were unstable, although the lake was at a much higher level than today, and the climate was generally more humid. The late-glacial paleolake Lejía was lower in salinity than Laguna Miscanti (Table 1, Figs. 1 and 3), the freshest lake in this area today. Table 1 shows that modern sediments in Laguna Miscanti exhibit higher $\mathrm{Mg} / \mathrm{Ca}$ ratios and higher $\mathrm{Sr} / \mathrm{Ca}$ ratios than all of the sediments of paleolake Lejía. The aqueous electrical conductivity in the current water of Laguna Miscanti is $6.4 \mathrm{mS} \mathrm{cm}^{-1}$ compared to $35 \mathrm{mS}$ $\mathrm{cm}^{-1}$ for Laguna Lejía today.

The sediments of the second unit $(111-225 \mathrm{~cm}$ deep, c. 13500 to $<10400{ }^{14} \mathrm{C}$ yr B.P. with reservoir correction) consist mainly of finely laminated calcareous sediments. They were deposited in a very calm environment corresponding to the maximum lake level, $25 \mathrm{~m}$ higher than today's level. Detritus is very sparse, consisting mainly of pyroclastic magnetite, feldspars, glasses, and a few lenses of fine sand. The $1.2 \mathrm{~m}$ thick, undisturbed and finely $(0.5-2 \mathrm{~mm})$ laminated carbonates have a lower $\mathrm{Mg} / \mathrm{Ca}$ ratio than in unit one, and the $\mathrm{Sr} / \mathrm{Ca}$ ratio is slowly decreasing (Table 1 ). Both suggest a trend towards fresher conditions, interpreted as being due to an increase in the lake level. Ripple marks and lateral slumping of sediments are very weak or absent, suggesting a calm, relatively deep-water environment (sublittoral to profundal facies). The lack of bioturbation suggests meromixis in the lake. As shown in the section between $118.5-119.5 \mathrm{~cm}$ (Fig. 3), the magnesian calcite layers, with occasional gypsum coprecipitation, alternate with deposits of diatoms and filamentous biogenic silica. These two phases are interpreted as seasonally-laminated calcareous sediments (O'Sullivan, 1983), with magnesian calcite precipitated during summer as the result of higher water temperatures and biologic activity, and bioclasts (mainly diatoms) accumulated during fall and winter due to the decay of plankton populations. Gypsum precipitation, as reflected by $S$ content (SEM-EDX), is believed to be the result of the saturation in the water, and tends to follow calcite precipitation in the summer layer. However, the exact timing of the gypsum precipitation in the annual cycle is not yet known. Since gypsum precipitates at the end of the dry season when evaporation in the lake is greatest, this information could provide evidence for the timing of the rainy season, which is an important element of the paleoclimate. Clastic input, as represented by $\mathrm{Al}$, correlates positively with $\mathrm{Si}$ from 
Table 1. $\mathrm{Mg} / \mathrm{Ca}$ and $\mathrm{Sr} / \mathrm{Ca}$ ratios in calcites of the late-glacial/early Holocene sedments from lake Lejía (profile see Figs. 2 and 3 ) and the modern lake Miscanti. The low ratios in the sediments of Laguna Lejía suggest that the late-glacial paleolake Lejía was fresher than the modern lake Miscanti, the freshest lake in the Altiplano today (electrical conductivity $6.4 \mathrm{mS} \mathrm{cm}^{-1}$ )

\begin{tabular}{lccccc}
\hline & Material & $\begin{array}{c}\text { Depth } \\
{[\mathrm{cm}]}\end{array}$ & $\begin{array}{c}1000 \mathrm{Mg} / \mathrm{Ca} \\
\text { average }\end{array}$ & \multicolumn{2}{c}{$\begin{array}{c}1000 \mathrm{Sr} / \mathrm{Ca} \\
\text { average }\end{array}$} \\
\cline { 2 - 6 } L. Lejía & calcite & $0-110$ & $46 \pm 19$ & $2.6 \pm 0.46$ & $n=35$ \\
& calcite & $111-223$ & $26 \pm 5$ & $2.9 \pm 0.66$ & $n=23$ \\
& calcite & $225-270$ & $46 \pm 10$ & $3.3 \pm 0.25$ & $n=11$ \\
& & & & & \\
L. Miscanti & calcite & $0-5$ & 90 & 3.7 & $n=2$ \\
\hline
\end{tabular}

diatom opal, and is characteristic for the fall/winter layer. The section that is between $115-120 \mathrm{~cm}$ deep (Fig. 3) gives an example of the sediments of unit 2 $(111-225 \mathrm{~cm})$. These $5 \mathrm{~cm}$ of laminated sediments are composed of 30-35 'annual' cycles representing about three decades of lake history. The $\mathrm{Mg}$ and $\mathrm{S}$ contents suggest that relatively stable environmental conditions prevailed for a few decades. This is in contrast to the section that is $256-261 \mathrm{~cm}$ deep and represents the first sediment unit. However, fluctuations in the lake are observed for the period of laminated sediments: the high $\mathrm{Mg} / \mathrm{Ca}$ and $\mathrm{Sr} / \mathrm{Ca}$ ratio, and the high gypsum content at a depth of $190 \mathrm{~cm}$ (Fig. 3, arrows) suggest short-term saline conditions in the lake during a dry period.

The annual deposits are $0.5-2 \mathrm{~mm}$ thick. It follows that the deposition of the sediments at depths between $225-111 \mathrm{~cm}$ took more than 1000 years under high lake level conditions. This in turn suggests that the high lake levels in the Altiplano were the result of a shift in the precipitation belts, with a general increase in precipitation and reduction of evaporation due to greater cloudiness. Kessler (1991) and Grosjean (1994) concluded earlier that the high lake levels could not have been produced exclusively by single storms or melting glaciers. They argue that, under current climatic conditions, the paleolakes would have dried out within less than 50 years, which is in contrast to the 1000 years of high lake levels as determined by the laminated sediments.

The uppermost sediment unit $(110-0 \mathrm{~cm}$ deep, $<10400$ to $c .8500$ (?) ${ }^{14} \mathrm{C}$ yr B.P. with reservoir correction) consists of reworked, downwashed 'older' lake sediments. Oscillation ripples, alternating beds of carbonates and sand are abundant. The sandy interlayers sometimes show normal grading. All these fea- tures provide evidence of fluctuating water levels. The mineralogy generally shows a mix of the underlying sediments, and the higher $\mathrm{Mg} / \mathrm{Ca}$ ratios (Table 1) suggest more saline conditions in the lake due to higher evaporation rates and decreasing lake volume.

A mineralogically interesting feature was found at a sediment depth of $50 \mathrm{~cm}$ (Fig. 2): hydrated calcite needles $\left(\mathrm{CaCO}_{3}^{*} 6 \mathrm{H}_{2} \mathrm{O}\right.$, ikaite?) form a characteristic $10 \mathrm{~cm}$ thick layer. The monocline ikaite (?) needles, up to $6 \mathrm{~cm}$ long, are preserved as calcite pseudomorphs. This is typical for hydrated calcites because they are metastable mineral phases under current climatic conditions. The presence of ikaite is important since it indicates calcite precipitation at temperatures around $0^{\circ} \mathrm{C}$ (Tucker \& Wright, 1990).

\section{The chronology of the Laguna Lejia sediments}

Discussion of the sediment chronology is purposely conservative, because determining the age of lake sediments in the extremely arid environment of the Altiplano is difficult. Therefore, the purpose of this section is to illustrate problems rather than to give a detailed chronology. The trouble is that no macroscopic terrestrial organic matter $\left(\mathrm{OM}_{\mathrm{t}}\right)$ could be found in the sediments. Therefore, we had to use both the aquatic $\mathrm{OM}_{\mathrm{aq}}$ and the carbonate fraction of sediments separately for radiocarbon dating (Fig. 4). Today, all dissolved inorganic carbon DIC compounds in the lake water of Laguna Lejía are derived from modern, atmospheric $\mathrm{CO}_{2}(100 \mathrm{pMC})$, from $\mathrm{HCO}_{3}^{-}$in groundwater inflow (e.g. $45.9 \mathrm{pMC}, \mathrm{Hv}-18084$ ) of one sample, and dissolved carbonates from old lake sediments. The values of 35.3-36.1 pMC (Hv-17802, Hv-18083) seem to be representative for present lake water, which corresponds to 8200 conventional ${ }^{14} \mathrm{C}$ years B.P. Since 
the live aquatic plants found in the lake today contain 79.3 pMC (corresponding to 1900 conventional ${ }^{14} \mathrm{C}$ years B.P., Hv-17880), they obviously assimilate a portion of the already aged carbon from the lake water. In conclusion, the radiocarbon ages of aquatic $\mathrm{OM}$ and precipitated carbonates in this lake are too large and have to be interpreted as maximum ages due to the discussed reservoir effect. This may be estimated by analysing modern lake water and live aquatic plants, where the correction values in Laguna Lejía are -2000 years for $\mathrm{OM}_{\mathrm{aq}}$ and -8000 years for carbonates. Assuming a constant reservoir effect, the laminated sediments were deposited between 13500 to $\sim 10000 \mathrm{yr}$ B.P. However, since we are not yet able to give a carbon mass balance for the lake and the different sources, we do not know how good the assumption of a constant reservoir effect really is. Therefore, we conclude conservatively - at this stage of the work a late-glacial, early Holocene age for the laminated sediments.

The similar ${ }^{14} \mathrm{C}$ ages of the carbonate fractions in the lake sediments (Fig. 4, Grosjean, 1994) suggest post-sedimentary dissolution and reprecipitation of carbonates. This finding is not surprising, since magnesian calcites are metastable precipitates with high dislocation densities and compositional heterogeneities at the atomic level (Tucker \& Wright, 1990: 301). SEM analysis showed that most of the calcite crystals are corroded. This observation suggests postsedimentary dissolution, and this in turn puts limits on the interpretation of the $\mathrm{Mg}$ and $\mathrm{Sr}$ partitioning in the calcite lattice.

In light of these difficulties, it is necessary to compare the dating results from several basins using carbon-independent dating techniques, e.g. thermoluminescence dating of volcanic tuff layers in sediments (Bürgi, 1992). Reservoir effects seem to be less important in the hydrologically open system of the Salar de Aguas Calientes I (Fig. 5) and in the Salar de Ollagüe $21^{\circ} \mathrm{S}$ (Grosjean, 1994). Stromatolites corresponding to the maximum lake level, about $40 \mathrm{~m}$ above the present lake levels, yielded ages of $13160 \pm 80 \mathrm{yr}$ B.P. (Beta63356) and $11300 \pm 70 \mathrm{yr}$ B.P. (Beta-63353), and laminated sediments were still deposited $10400 \pm 75 \mathrm{yr}$ B.P. Since all of these ages are maximum ages due to an unknown reservoir effect, we conclude conservatively a late-glacial to early Holocene age for the maximum humid phase in the Altiplano.

\section{Recharge of groundwater today}

Several ground- and surface waters were analyzed for their ${ }^{3} \mathrm{H}$ and ${ }^{14} \mathrm{C}$ content in order to estimate the proportions of old and young components in bodies of water in the Altiplano (Fig. 5). In order to interpret the radiocarbon data, different sources of carbon had to be evaluated (see also Fig. 4), including atmospheric $\mathrm{CO}_{2}$ of infiltrating rain water, biogenic $\mathrm{CO}_{2}$, carbonate from weathered bedrock or dissolved lake sediments, soil $\mathrm{CO}_{2}$, and volcanic-hydrothermal carbon.

The volcanic rocks in the study area are free of major carbonate sequences. Although chemical weathering is slow in this area, the alteration of abundant plagioclase may produce carbonates. In addition, volcanic $\mathrm{CO}_{2}$ may have serious implications for determination of groundwater age. The significance of this carbon source and of soil $\mathrm{CO}_{2}$ in the Atacama basin and the Pampa de Tamarugal is discussed in Fritz et al. (1979). In our study, chemical compositions help to identify the hydrothermal component in the water samples. Some typical results are listed in Table 2, and Fig. 5 shows the sample sites.

The ${ }^{14} \mathrm{C}$ values of the water samples vary between 70.7 and $8.6 \mathrm{pMC}$. For instance, the high sulfate and chloride values of Quebrada Toro suggest a hydrothermal component in the water. This source adds a proportion of 'dead' $\mathrm{C}$ to the DIC reservoir, making the water appear older than it really is (i.e. age calculated starting with atmospheric values for ${ }^{14} \mathrm{C}$ ). The sample from Salar Aguas Calientes I shows this effect to some extent, while the high mineralisation in the lake water of Laguna Lejía is due to concentration of ions in the brine. Although the surface water is in continuous carbon exchange with the 'modern' atmosphere, the level of ${ }^{14} \mathrm{C}$ in open water bodies is low. We conclude that there is a significant contribution from an old water reservoir, which is recharged only on time scales of centuries to millenia. This situation seems to be typical for the Atacama area.

Tritium ${ }^{3} \mathrm{H}$ was measured in order to evaluate the modern water component. Modern continental rainfall in south America at approximately $24^{\circ} \mathrm{S}$ can be expected to have concentrations $>4 \mathrm{TU}$ (tritium units), whereas rainfall from the Pacific without admixture of re-evaporated continental moisture is on the order of 2 TU (IAEA/WMO, 1994). All the analyzed snow and ice samples from different seasons (Table 3) contain tritium concentrations between 2.9 and $9.6 \mathrm{TU}$, suggesting that the moisture source is mainly continental. This finding is in agreement with Fuenzalida \& 


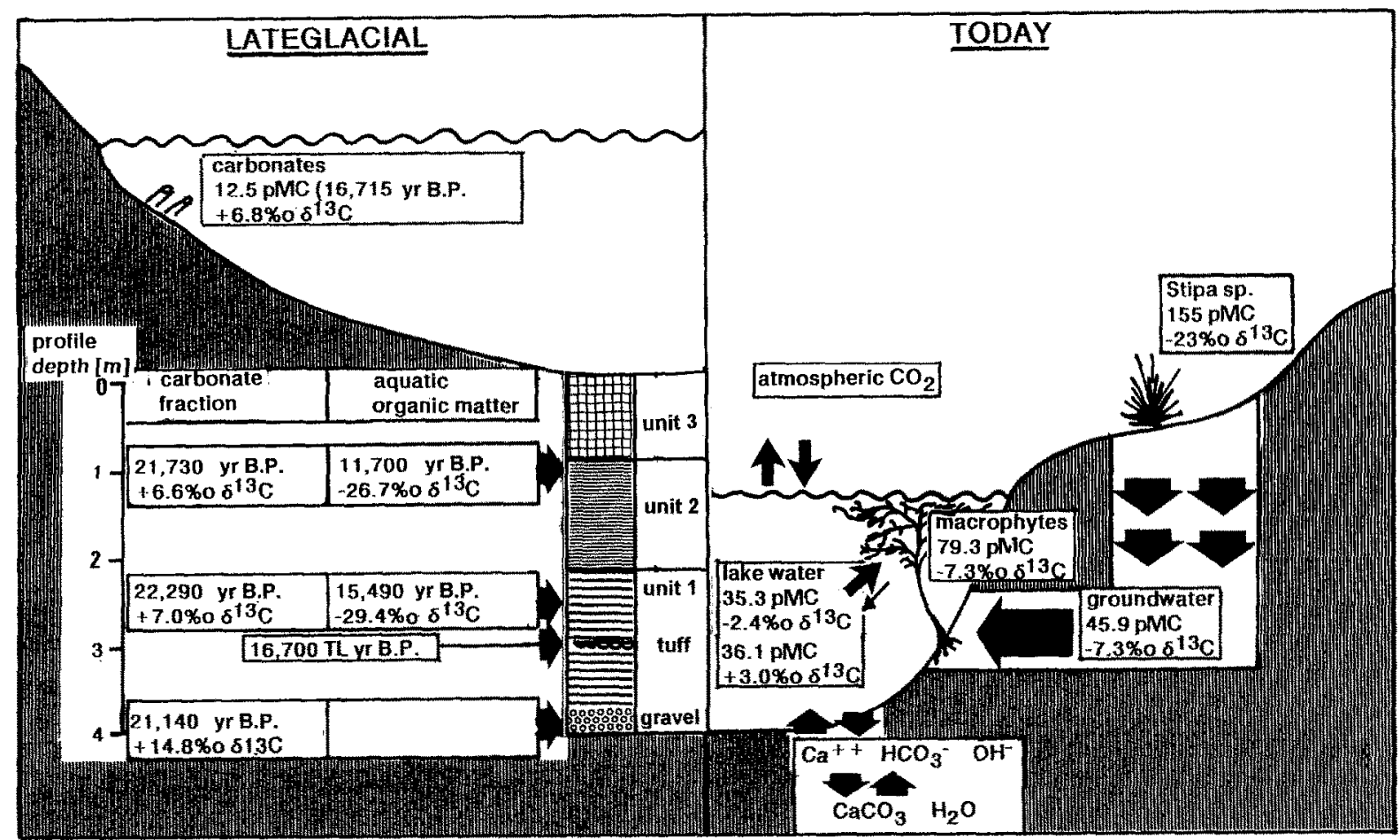

Fig. 4. Conventional radiocarbon dates (percent modern carbon $\mathrm{pMC}$ ) and $\mathrm{d}^{13} \mathrm{C}$ on aquatic organic matter, carbonates, and water in the Laguna Lejía. The figure on the right shows the $\mathrm{C}$ sources and the reservoir effect for the modern lake water and live aquatic organic matter. The figure on the left shows the entire late Pleistocene/early Holocene sediment section. The ${ }^{14} \mathrm{C}$ ages of aquatic OM and carbonates are subject to the reservoir effect. The similar ages of the carbonate fraction in the entire section suggest post-sedimentary dissolution and reprecipitation of calcites in the sediment column.

Table 2. ${ }^{14} \mathrm{C}$ and tritium values, and chemical composition of water samples from the Atacama Altiplano. For sample sites, see Fig. 5

\begin{tabular}{|c|c|c|c|c|c|c|c|c|c|c|c|c|c|c|}
\hline locality & $\begin{array}{l}\text { sample } \\
\text { Lab \# }\end{array}$ & $\begin{array}{l}{ }^{14} \mathrm{C} \\
\mathrm{pMC}\end{array}$ & $\begin{array}{c}\mathrm{d}^{13} \mathrm{C} \\
\% \circ \mathrm{PDB}\end{array}$ & $\begin{array}{l}{ }^{3} \mathrm{H} \\
\mathrm{TU}\end{array}$ & $\begin{array}{l}\text { el. cond. } \\
\mathrm{mS} \mathrm{cm}^{-1}\end{array}$ & $\begin{array}{l}\text { Temp. } \\
{ }^{\circ} \mathrm{C}\end{array}$ & $\mathrm{pH}$ & $\begin{array}{l}\mathrm{HCO}_{3}^{-} \\
\mathrm{mg} \mathrm{I}^{-1}\end{array}$ & $\begin{array}{c}\mathrm{Cl}^{-} \\
\mathrm{mg} \mathrm{l}^{-1}\end{array}$ & $\begin{array}{l}\mathrm{SO}_{4}^{2-} \\
\mathrm{mg} \mathrm{l}^{-1}\end{array}$ & $\begin{array}{c}\mathrm{NA}^{+} \\
\mathrm{mg} \mathrm{l}^{-1}\end{array}$ & $\begin{array}{c}\mathrm{K}^{+} \\
\mathrm{mg} \mathrm{l}^{-1}\end{array}$ & $\begin{array}{c}\mathrm{Ca}^{2+} \\
\mathrm{mg} \mathrm{l}^{-1}\end{array}$ & $\begin{array}{l}\mathrm{Mg}^{2+} \\
\mathrm{mg} \mathrm{l}^{-1}\end{array}$ \\
\hline L. Lejía & $\begin{array}{l}\text { lake water } \\
\text { Hv-17802 }\end{array}$ & 35.3 & -2.4 & 1.9 & 35 & & 8.7 & $\sim 5040$ & 9900 & 28000 & 1600 & 1400 & 127 & 5900 \\
\hline L. Lejía & $\begin{array}{l}\text { groundwater N } \\
\text { Hv-18084 }\end{array}$ & 45.9 & -7.3 & $<0.3$ & 0.9 & 6 & 7.3 & 151 & 67 & 290 & 83 & 10 & 18 & 67 \\
\hline L. Lejia & $\begin{array}{l}\text { lateral lagune } \\
\mathrm{Hv}-18560\end{array}$ & 26.4 & -6.9 & & 1.6 & 7.4 & 8.3 & 189 & 180 & 340 & 250 & 22 & 16 & 58 \\
\hline Q. Toro & $\begin{array}{l}\text { pond, spring } \\
\mathrm{Hv}-17804\end{array}$ & 8.6 & 2.7 & $<0.3$ & 5.3 & 8.2 & 7.8 & 1638 & 720 & 900 & nd & nd & 15 & 80 \\
\hline Q. Toro & $\begin{array}{l}\text { end of creek } \\
\mathrm{Hy}-17805\end{array}$ & 36.4 & 1.3 & & 2.4 & 14.2 & 8.4 & 580 & 320 & 360 & nd & nd & 18 & 52 \\
\hline Tumbre & $\begin{array}{l}\text { spring } \\
\mathrm{Hv}-18562\end{array}$ & 19.8 & -8.6 & $<0.3$ & 0.5 & nd & 7.5 & 189 & 33 & 72 & nd & nd & 10 & 34 \\
\hline Linzor & $\begin{array}{l}\text { creek } \\
\text { Hv- } 18563\end{array}$ & 56.3 & -8.3 & $<0.4$ & 0.7 & 16.1 & 7.7 & 113 & 112 & 70 & nd & nd & 4 & 14 \\
\hline $\begin{array}{l}\text { S. Ag. } \\
\text { Cal. I }\end{array}$ & $\begin{array}{l}\text { spring } \\
\text { Hv-18566 }\end{array}$ & 10.7 & -11.2 & 0.7 & 1.9 & 16.9 & nd & nd & nd & nd & nd & nd & nd & nd \\
\hline
\end{tabular}




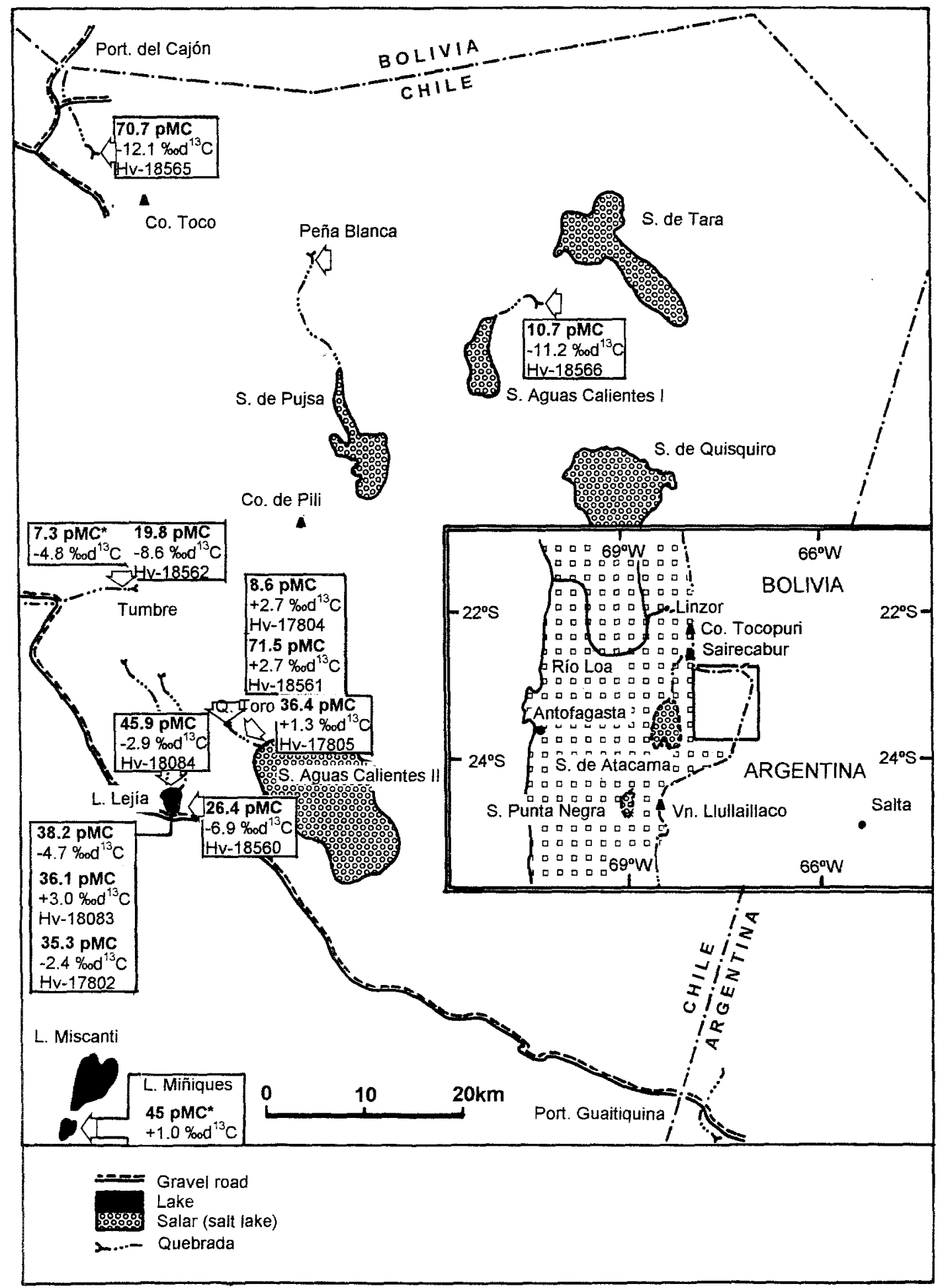

Fig. 5. ${ }^{14} \mathrm{C}$ concentrations and $\mathrm{d}^{13} \mathrm{C}$ data of water samples in the Atacama Altiplano. The data on water chemistry are listed in Table $2 .{ }^{*}$ data from Fritz et al., 1979. 
Rutllant (1986) and Aravena et al. (1989). Therefore, we conclude that water samples with concentrations below the detection limit $<0.4$ TU contain less than $10-20 \%$ of modern water, i.e. water which recharged within the last 40 years.

The tritium concentrations in the water samples follow the general precipitation pattern: values less than $1 \mathrm{TU}$ or even below the detection limit are measured in groundwater and surface waters at lower elevations, generally more in the dry western part of the Andes down to the coast. At higher elevations and in smaller catchments situated in the Altiplano and to the more humid east, the modern component becomes increasingly important (Messerli et al., 1993). The values for lakes, creeks and ponds in our research area in the Altiplano range between $<0.4-<2$ TU (Table 3 ). Worthy of note are the lakes which collect precipitation, and show tritium values up to $1.9 \mathrm{TU}$, which corresponds to $<50 \%$ modern water. Springs and groundwater contain the lowest ${ }^{3} \mathrm{H}$ concentrations of $<0.4-<1 \mathrm{TU}$ and, therefore, less than 10-20\% modern water. The groundwater near Laguna Lejía is somewhat higher in tritium because it has a proportion of tritium from the lake.

Identification of the continent as the dominant moisture source is an important result in light of the atmospheric circulation during late-glacial times. Markgraf (1989), Kessler (1991), Messerli et al. (1993) and Grosjean (1994) postulate strengthened monsoonal circulation with moisture advection from the tropical continent to account for the humid climate in the Altiplano. Therefore, it is suggested that the moisture source likely was the same during late-glacial times as it is today, i.e. continental. Modern circulation patterns and precipitation processes (Fuenzalida \& Rutllant, 1986; Aravena et al., 1989) may, therefore, constitute a framework that is analogous to circulation during the late-glacial and early Holocene time in the Altiplano. This implies that the atmospheric flow pattern was the same as today, but heavily intensified, i.e. the modern precipitation-bearing circulation modes were statistically more abundant.

\section{Conclusions}

Lake sediments from Laguna Legía in the Atacama Altiplano indicate climatic conditions that were significantly wetter during late-glacial and early Holocene times than they are today. Initially (c. $15400-13500 \mathrm{yr}$ B.P.), the salinity of the lake was a little higher than dur- ing the maximum lake phase, when freshwater conditions prevailed. During the main lake phase (c. 13500 $<10400$ yr B.P.), seasonally-laminated calcareous sediments were deposited in a $25 \mathrm{~m}$ deep lake. The environment was characterized by relative stability on a decadal to centennial time scale, as determined from the laminated sediments. However, some fluctuations in the environment can be observed. During the early Holocene, conditions in the lake were similar to those during the initial lake phase, still at a generally higher level than today.

The seasonally-laminated calcareous sediments suggest that the high lake levels were the result of a general shift of the climate to long-term-stable, more humid conditions. These high-lake-level conditions lasted for more than 1000 years, and were not the result of climatic peculiarities or melting glaciers.

The laminae represent seasonal deposits. Therefore, they provide a potential archive for highresolution climatic information in an area where paleoenvironmental information is still scarce.

Terrestrial OM for radiocarbon dating was not found in these lake sediments. Therefore, aquatic $\mathrm{OM}$ or carbonates have to be used for ${ }^{14} \mathrm{C}$ dating. Both materials are subject to the reservoir effect. For today's correction values in the Laguna Lejía we used -2000 yrs for aquatic OM and -8000 yrs for carbonates. A precise chronology of the major climatic events has yet to be fully established, and comparisons with other, $\mathrm{C}$-independent dating techniques are needed. However, based on the data available today, we conclude a late-glacial to early Holocene age for the maximum humid phase.

We conclude from radiocarbon and tritium results that modern recharge of the main water bodies in the Atacama Altiplano is slow and limited. We suggest that the late-glacial/early Holocene humid climates, with more than twice as much precipitation as today accounted for much of the groundwater resources in this area today.

Tritium values of modern precipitation provide evidence of the continental origin of the water vapour. Since strengthened tropical rainfall is believed to have caused the humid phase in the Altiplano, it follows that studies of present-day circulation patterns and precipitation formation can be useful in reconstructing lateglacial atmospheric circulation in the Altiplano. 
Table 3. Tritium values of snow, ice and firn samples, open water bodies, and spring and groundwater samples in the Atacama Altiplano. For sample sites, see Fig. 5 ( $^{*}$ data IAEA/WMO, 1994)

\begin{tabular}{|c|c|c|c|c|}
\hline Date & Locality & $\begin{array}{c}\text { Elevation material } \\
\mathrm{m}\end{array}$ & $\begin{array}{l}\text { Tritium } \\
\text { TU }\end{array}$ & $\pm 2 \sigma$ \\
\hline \multicolumn{5}{|c|}{ snow, ice and firn samples } \\
\hline & continental rainfall* & & $>4$ & \\
\hline & Pacific rainfall* & & $<2$ & \\
\hline 20-Apr-90 & Llullaillaco $-2 \mathrm{~cm}$ & 6200 snow $-2 \mathrm{~cm}$ & 5.27 & \pm 0.37 \\
\hline 20-Apr-90 & Llullaillaco $-50 \mathrm{~cm}$ & 6200 ice $-50 \mathrm{~cm}$ & 9.60 & \pm 0.40 \\
\hline 20-Apr-90 & Llullaillaco $-300 \mathrm{~cm}$ & $6200 \mathrm{fim}-300 \mathrm{~cm}$ & 6.37 & \pm 0.36 \\
\hline 20-Apr-90 & Llullaillaco $-320 \mathrm{~cm}$ & $6200 \mathrm{firn}-320 \mathrm{~cm}$ & 6.49 & \pm 0.48 \\
\hline 2-Feb-93 & Sairecabur & 5800 fresh snow & 5.33 & \pm 0.32 \\
\hline 20-May-90 & Ojos del Salado & 4500 fresh snow & 6.22 & \pm 0.38 \\
\hline 16-Dec-88 & Cerro Pili & 5700 melt water & 4.19 & \pm 0.51 \\
\hline 16-Dec-88 & Cerro Pili & 5700 snow $-50 \mathrm{~cm}$ & 4.85 & \pm 0.57 \\
\hline 16-Dec-88 & Cerro Pili & 5700 snow $-25 \mathrm{~cm}$ & 3,68 & \pm 0.44 \\
\hline 3-Apr-91 & Cerro Toco N & 4700 fresh snow & 2.91 & \pm 0.29 \\
\hline 7-Apr-91 & Cerro Tocopuri & 5400 fresh snow & 3.60 & \pm 0.33 \\
\hline \multicolumn{5}{|c|}{ lakes, creeks and ponds } \\
\hline $10-$ Nov-91 & Rio Linzor & 3980 creek & $<0.4$ & \\
\hline 19-Nov-91 & Cerro Toco $\mathrm{N}$ & 4580 pond & $<0.4$ & \\
\hline 3-Apr-91 & Cerro Toco N & 4640 creek & $<0.4$ & \\
\hline 10-Apr-91 & Laguna Lejía & 4300 lake & 1.90 & 0.34 \\
\hline 9-Dec-88 & Laguna Lejía & 4300 lake & 0.94 & 0.38 \\
\hline 8-Dec-88 & Salar Aguas Calientes I & 4100 salar water & 0.73 & 0.46 \\
\hline 3-Apr-91 & Pena Blanca & 4580 creek & 1.37 & 0.32 \\
\hline 11-Dec-88 & Pena Blanca & 4580 creek & 1.69 & 0.49 \\
\hline \multicolumn{5}{|c|}{ springs and groundwater } \\
\hline 28-Mar-91 & Talabre & 3800 spring & $<0.4$ & \\
\hline 29-Mar-91 & Laguna Lejía N, $-170 \mathrm{~cm}$ & 4300 groundwater & $<0.4$ & \\
\hline $20-$ Nov-91 & Laguna Lejía $\mathrm{N},-170 \mathrm{~cm}$ & 4300 groundwater & $<0.4$ & \\
\hline 11-Apr-91 & Laguna Lejía NW, $-60 \mathrm{~cm}$ & 4300 groundwater & $<0.4$ & \\
\hline 9-Dec-88 & Laguna Lejía NW & $4300 \mathrm{mix}$ gw/lake & 0.80 & 0.40 \\
\hline 9-Dec-88 & Laguna Lejía SW & 4300 groundwater & 1.78 & 0.35 \\
\hline 9-Dec-88 & Laguna Lejía SE & 4300 groundwater & 1.07 & 0.47 \\
\hline 9-Dec-88 & Laguna Lejía NE & 4300 groundwater & 0.76 & 0.49 \\
\hline 3-Apr-91 & Pena Blanca & 4650 spring & $<0.4$ & \\
\hline 27-Nov-91 & Toro Blanco (Hans) & 4360 spring & $<0.4$ & \\
\hline 8-Dec-88 & Salar Aguas Calientes I & 4100 thermal spring & $<0.4$ & \\
\hline 8-Dec-88 & Salar Aguas Calientes I & 4100 spring $1, \mathrm{NE}$ & 0.70 & 0.46 \\
\hline 8-Dec-88 & Salar Aguas Calientes I & 4100 spring $2, \mathrm{NE}$ & 0.89 & 0.38 \\
\hline
\end{tabular}

\section{Acknowledgements}

This study was financed with grants from the Swiss National Science Foundation (NF 20-36382.92) project 'Climate Change in the Arid Andes'. Les Lavkulich and Hans Schreier (Dept. of Soil Science,
UBC, Vancouver) generously provided the laboratory facilities for all the chemical and mineralogical analysis of the sediments. We thank Willi Egli and Marcela Espinoza N. (DIFROL) for logistical support and for granting permission to conduct research, and the two anonymous reviewers for constructive comments. 


\section{References}

Aravena, R., H. Peña, A. Grilli, O. Suzuki \& M. Mordeckai, 1989. Evolucion isotopica de las lluvias y origen de las masas de aire en el Altiplano chileno. IAEA-TECDOC-502: 129-142.

Baied, C. A. \& J. C. Wheeler, 1993. Evolution of high Andean ecosystems: Environment, climate, and cultural change over the last 12000 years in the Central Andes. Mountain Research and Development 13: 145-156.

Bürgi, A., 1992. Aufbau und Betrieb eines ThermolumineszensLabors zur Datierung quartaergeschichtlicher Proben. Ph.D. dissertation, University of Bern: $121 \mathrm{pp}$.

Chivas, A. R., P. De Deckker \& J. M. G. Shelly, 1986. Magnesium and strontium in non-marine ostracod shells as indicators of palaeosalinity and palaeotemperature. Hydrobiologia 143: 135142.

Fritz, P., C. H. Silva, O. Suzuki \& E. Salati, 1979. Isotope Hydrology in Northern Chile. IAEA-SM-228/26: 525-543.

Fuenzalida, H. \& J. Rutllant, 1986. Estudio sobre el origen del vapor de agua que precipita en el invierno altiplanico. Informe final. Universidad de Chile: $51 \mathrm{pp}$.

Goldsmith, J. R. \& D. L. Graf, 1958. Relation between lattice constants and composition of the $\mathrm{Ca}-\mathrm{Mg}$ carbonates. Am. Mineralogist 43: 84-101.

Grosjean, M., 1994. Paleohydrology of the Laguna Lejía (Northchilean Altiplano) and climatic implications for lateglacial times. Palaeogeography, Palaeoclimatology, Palaeoecology 109: 89-100.

Grosjean, M. \& L. Nuñez, 1994. Late-glacial, Early and Middle Holocene Environments, Human Occupation and Resource Use in the Atacama (Northern Chile). Geoarchaeology 9: 271-286.
IAEA/WMO, 1994. Network of Isotopes in Precipitation. NGDC/WDC-A Paleoenvironmental Data Sets. Boulder.

Kessler, A., 1991. Zur Klimaentwicklung auf dem Altiplano seit dem letzten Pluvial. Freiburger Geographische Hefte 32: 141-148.

Markgraf, V., 1989. Paleoclimates in Central and South America since $18000 \mathrm{BP}$ based on pollen and lake-level records. Quat. Sci. Rev. 8: 1-24.

Messerli, B., M. Grosjean, G. Bonani, A. Bürgi, M. A. Geyh, K. Graf, K. Ramseyer, H. Romero, U. Schotterer, H. Schreier \& M. Vuille, 1993. Climate Change and Natural Resource Dynamics of the Atacama Altiplano During the Last 18000 Years: A Preliminary Synthesis. Mountain Research and Development 13: 117-127.

Nuñez, L. A., 1992. Ocupacion arcaica en la Puna de Atacama: secuencia, movilidad y cambio. In B. J. Meggers (ed.), Prehistoria Sudamericana. Nuevas Perspectivas. Taraxacum, Washington: 283-307.

Ruddiman, W. F. \& J. E. Kutzbach, 1991. Plateaubildung und Klimaänderung. Spektrum der Wissenschaften 5/91: 114-125.

Ochsenius, C., 1986. La glaciacion Puna durante el Wisconsin, deglaciacion y maximo lacustre en la tradicion WisconsinHoloceno y refugios de la megafauna postglaciales en la Puna y desierto de Atacama. Revista de Geografia Norte Grande 13: 29-58.

O'Sullivan, P.E., 1983. Annually-laminated lake sediments and the study of quaternary environmental changes - a review. Quat. Sci. Rev. 2: 245-311.

Tucker, M. E. \& V. P. Wright, 1990. Carbonate Sedimentology. Blackwell Scientific Publications, Oxford: 481 pp. 